\title{
GATA5 wt Allele
}

National Cancer Institute

\section{Source}

National Cancer Institute. GATA5 wt Allele. NCI Thesaurus. Code C60658.

Human GATA5 is located within $20 \mathrm{q} 13.33$ and is approximately $12 \mathrm{~kb}$ in length. This gene, which encodes transcription factor GATA-5 protein, plays a role in the transcriptional regulation of intestinal lactase-phlorizin hydrolase activity and in cardiac smooth muscle cell function. 